\title{
Üniversitede Öğrenim Gören Elit Düzey Bocce Sporcularının Rekreasyon Faaliyetlerine Yönelik Tatmin ve Benlik Alg1sı Düzeyleri Arasındaki İlişkinin İncelenmesi ${ }^{1}$
}

\author{
Fatih YAȘARTÜRK ${ }^{2}$ ve Okan AYDIN ${ }^{3}$
}

\section{Öz}

$\mathrm{Bu}$ araştırma üniversitede öğrenim gören elit düzey bocce sporcularının rekreasyon faaliyetlerine yönelik tatmin ve benlik algısı düzeyleri arasındaki ilişkinin incelenmesi amacıyla yapılmıştır. Araştırmaya üniversitelerde öğrenim gören, 106 (57 kadın ve 49 erkek) gönüllü elit düzey bocce sporcuları katılım sağlamıstır. Araştırmada, katılımcıların benlik alg1 düzeylerinin ölçülmesi amacıyla Marsh, Hey, Johnson ve Perry (1997) tarafından geliştirilen Çağlar, Aşçı ve Kelecek (2017) tarafindan Türkçe geçerlilik ve güvenilirlik çalışması yapılan "Elit Sporcu Benlik Algısı Envanteri (ESBAE)" kullanılmıştır. Ayrıca katılımcıların rekreasyon faaliyetlerine yönelik tatminlerin ölçülmesi amacı ile Beard ve Ragheb (1980) tarafindan geliştirilen Karlı, Polat, Yılmaz ve Koçak (2008) tarafından Türkçeye uyarlanıp geçerlilik ve güvenilirlik çalışması yapılan "Serbest Zaman Tatmin Ölçeği (SZTÖ)" kullanılmıştır. Ayrıca elde edilen verilen SPSS 23.0 paket programında çözümlenmiştir. Verilerin analizinde betimsel istatistik, t-testi, Kruskal Wallis, Pearson Korelasyon katsayısı ile analiz yapılmıştır. Araştırmanın bulgularında, t-Testi sonuçlarında "cinsiyet” değişkenine göre ESBAE "algılanan beceri”, "vücut uygunluğu”, "aerobik uygunluk", "genel performans", "toplam benlik alg1sı" ve SZTÖ "psikolojik tatmin" alt boyutlarının anlamlı farklılık gösterdiği belirlenmiştir $(p<0,05)$ ve kadın sporcuların lehine daha yüksek düzeyde olduğu saptanmıștır. Ayrıca sporcularının benlik algıları ile serbest zaman tatminleri arasında pozitif yönde ve orta düzeyde bir ilişki olduğu belirlenmiştir. Araștırmadan elde edilen bulgular doğrultusunda katılımcıların benlik saygısı ve serbest zaman tatmin düzeylerinin yüksek olduğu söylenebilir.

Anabtar Kelimeler: Elit Düzey Bocce Sporcular1, Serbest Zaman Tatmin, Benlik Alg1s1

Investigation of the Relationship between Satisfaction and Self Perception Levels of Recreational Activities of Elite Level Bocce Athletes Studying in University

\begin{abstract}
This study was conducted to investigate the relationship between satisfaction and self-perception levels of recreational activities of elite bocce athletes studying at university. 106 volunteer elite bocce athletes ( 57 females and 49 males) from universities participated in the study. In order to measure the self-perception levels of the participants, "Elite Sportsman Self-Perception Inventory (ESBAE)", which was developed by Marsh, Hey, Johnson, and Perry (1997) and whose Turkish validity and reliability study was used. In addition, Leisure Satisfaction Scale (LSS), which was developed by Beard and Ragheb (1980) by Karli, Polat, Yilmaz and Kocak (2008), was used to measure the satisfaction of the participants in recreation activities. In addition, the obtained SPSS 23.0 package program was analyzed. In the analysis of the data descriptive statistics, t-test, Kruskal Wallis, Pearson Correlation coefficient was analyzed. In the findings of the study, it was determined that ESBAE "perceived skill", "body fitness", "aerobic fitness", "overall performance", "total self-perception" and SZT "psychological satisfaction" sub-dimensions differed according to the "gender" variable. $(\mathrm{p}<0.05)$ and it was found to be higher in favor of female athletes. In addition, there was a positive and moderate relationship between selfperception of athletes and free time satisfaction. In line with the findings obtained from the research, it can be said that the participants' self-esteem and free time satisfaction levels are high.
\end{abstract}

Key Words: Elite Level Bocce Athletes, Leisure Satisfaction, Self-Perception

\section{Atıf İçin / Please Cite As:}

Yaşartürk, F. ve Aydın, O. (2020). Üniversitede öğrenim gören elit düzey bocce sporcularının rekreasyon faaliyetlerine yönelik tatmin ve benlik algısı düzeyleri arasındaki ilişkinin incelenmesi. Manas Sosyal Araştrrmalar Dergisi, 9(1), 449-461.

\footnotetext{
${ }^{1}$ Bu çalışma Bartın Üniversitesi, Eğitim Bilimleri Enstitüsü, Beden Eğitimi ve Spor Öğretimi Anabilim Dalında, Doç. Dr. Fatih YAŞARTÜRK danışmanlığında Yüksek Lisans tezi olarak yürütülmüştür.

2 Doç. Dr. - Bartın Üniversitesi Spor Bilimleri Fakültesi, fatihyasarturk@gmail.com - ORCID: 0000-0003-4934-101X

${ }_{3}^{3}$ Bartın Üniversitesi Eğitim Bilimleri Enstitüsü, okann.aydinn@gmail.com - ORCID: 0000-0002-7130-0831
} 


\section{Giriş}

Spor günümüz toplumlarında insanoğlunun vazgeçemediği eylemlerden biri haline gelmiştir. Bireylerin isteğine göre şekillenip çok çeşitli spor branşlanı meydana gelmiştir. Spor her yaş grubuna yönelik amatör veya profesyonel bir şekilde uygulanabilen ve geniş kitlelere hitap eden bir izleyici kitlesine sahiptir.

Spor; insanoğlunun ilk zamanlarından itibaren var olup günümüzde bile netleşmiş bir tanıma sahip değildir. Kişilerin icra ettikleri eylemlerden bazıları spor olarak nitelendirilmektedir. Kendine has kurallara sahip ve izleyene keyif veren mutlu eden rekabetçi yapıya sahip aktivitelerdir (Zorba, 2006).

Bocce, insanların geneli tarafindan bilinen ve izlenen futbol, basketbol voleybol vb. spor dallarından biri olmamasına rağmen her gün artan oyuncusu ve izleyicisiyle yurt içinde ve dışında büyük kitlelere ulaşmış bir tür spor dalıdır. Bocce sistemi dört farklı oyundan oluşmaktadır. Bunlar raffa, volo, petank ve çim topudur (Tükenmez, 2014). Anadolu topraklarını boccenin doğduğu yer olarak nitelendirmemiz yanlış olmaz. Antik dönemlerde ki buluntular bir yana, ilk çağlar da Avrupa medeniyetlerinin bocce sporunu Anadolu medeniyetlerinden öğrendiği söylenebilir. Roma imparatorluğuna aktarımın M.Ö. 600'lü yıllarda Anadolu'da yaşayan Yunanlılar tarafından olduğunu heykel ve resimlerden bu çıkarıma ulaşıldığını tarihçiler söylemektedir (Türkmen, 2011). Bocce branşının yaygınlaşması ülkemizde de elit düzey sporcular yetişmesini teşvik etmektedir. Özellikle son ylllarda alınan Balkan, Avrupa ve Dünya dereceleri ülkemizde bocce branşına olan yoğunluğu arttırmakta ve bu sporcuları etkileyen faktörlerin incelenmesinde ilgi kaynağı olmaktadır.

Benlik kavramı, insanın kendine karşı olan bakış açısı ve kendisini algılaması olarak ifade edilebilir. Kişi kendisinin kim olduğuna dair bulduğu cevaplar; niteliklerine, yetkinliklerine, kişisel ve toplumsal değer yargılarına, gaye ve ilkelerine yöneliktir. Doğum sonrası bebekler çevresiyle bedenini bir bütün olarak görürler ve zaman içerisinde ihtiyaçları doğrultusunda bedenlerinin farkına varırlar. Bununla beraber benliğinin ilk kavranması oluşmaya başlanır. Illk etapta ile sonrasında çevre ile bu etkileşim devam eder. Benlik gelişiminin olumlu yönde olabilmesi için çocukluğundan itibaren, aile ve çevre tarafindan bireye ilgi ve alaka, sevgi, güven, öz sayg1, kabul görme hissinin verilmesi gerekmektedir. Bunlar olumsuz şekilde gelişirse benlik gelişimde olumsuz bir hal alır. (Megep, 2013). Bir başka tanım ise benlik algısını şu şekilde özetler, "Hayatın ilk yıllarında başlayarak kişinin çevresiyle etkileşimi sonucu kazandığı geri bildirimler ve birebir yaşadığ1 tecrübeler ile oluşur" (Kuzgun, 1996).

Benlik (self), sosyal psikolojide önemli araştırma konularından biri olarak karşımıza çıkmaktadır. Tarihsel olarak da sosyal psikologların üzerinde durdukları ilk konular arasında yer alır. Benlik kavramı (self-concept) terimi, kişinin, kendi hakkındaki düşüncelerinin bütününü ifade etmektedir. Bu açıdan benlik kavramı, kişinin kendisi, vasıfları ve özellikleri hakkında sahip olduğu genel fikir olarak tanımlanabilir; dolayısıyla bir kişinin, kendisine ilişkin bilişsel temsillerini içeren algılarının bir özeti gibi düşünülebilir (Yavuzer, 2001).

Fiziksel benlik alg1sı, fiziksel aktivite ve sosyal beceri ilişkisine bakıldığında; düzenli fiziksel aktivite faaliyetleri bireylerin fiziksel görünüşlerini istenilen şekle getirdiği gibi beden imgesi ve benlik saygısını olumlu açıdan etkilemektedir. Düzenli fiziksel aktivite gerçekleştiren bireylerin benlik algıları, düzenli fiziksel aktivite yapmayanlardan anlamlı düzeyde yüksek bulunmuştur (Kuru, 2003). Bütün spor branşların da etkili olacağı düşünüldüğü gibi bocce branşında da benlik algısı önemli bir faktör olarak yer almaktadır. $\mathrm{Bu}$ yüzden, serbest zamanda bireylere mutluluk, doyum ve tecrübe kazanımı sağlayan rekreasyon faaliyetleri benlik algisı üzerinde etkili olacağı düşünülmektedir.

Rekreasyon, spor, fiziksel egzersiz, sanat ve oyun formlarını kullanarak kişiliğin yaratıı bir şekilde ifade edilmesi anlamına gelen bir kavramdır. Hareketten daha çok duyguları konu edinen rekreasyon, serbest zamanda bireysel doyum beklentisi ile yer alınan aktivitelerdir. Bireysel bir karşıllktır, psikolojik bir reaksiyondur, bir tutumdur, bir yaklaşımdır, bir yaşam biçimidir (Tekin, Amman \& Tekin, 2009).

Kişilerin sosyal, psikolojik ve kültürel açıdan gelişiminde etkili olan serbest zaman faaliyetleri insanın topluma sosyal ve ekonomik açıdan daha çok katkıda bulunmasına imkân sağlamaktadır. Serbest zamanların önemli olmasının bir sebebi de bireylerde çeşitli doyumlara yol açmasıdır. Bir başka yönüyle boş zaman faaliyetleri, bireylerin sosyalleşmesi toplumla bütünleşmesi gibi açılardan da etkili olabilmektedir (Özkalp, 1997). 
Bireylerin katıldıkları serbest zaman etkinliklerinden istedikleri faydayı sağlayıp sağlayamadıklarını, beklentilerini karşılayıp karşılamadıklarını ve bu faaliyetlere katılmaktan dolayı mutlu olup olmadıklarını ölçmek, onların serbest zamanlarını değerlendirirken daha mutlu ve tatminkâr olmalarını sağlayacak tedbirlerin alınmasında ve onların memnuniyet düzeyleri doğrultusunda sağlanan serbest zaman etkinliklerini geliştirmekte ve hatta etkinlik yelpazesini genişletmekte önemli bilgiler sağlayabilir (Karll, Polat, Yılmaz ve Koçak 2008). Serbest zaman doyum kavramı ise bireylerin serbest rekreatif etkinlikler sonunda bireysel ihtiyaçlarını karşılamaları sonucunda edindikleri pozitif duygular olarak tanımlanmaktadır (Siegenthaler ve O’Dell, 1998). Serbest zaman etkinliklerine özellikle aktif olarak katılımın bireyde olumlu duygular oluşturduğu yönünde çeşitli araştırmalar mevcuttur (Caldwell vd., 1992; Murphy, 2003; Şener, 2009; Yaşartürk, vd., 2017). Ayrıca serbest zaman doyumu, kişilerin serbest zaman etkinliklerinden algiladığı doyum düzeyini gösterir (Du Cap, 2002).

Bu bilgiler ışığında araştırmanın amacı, üniversitede öğrenim gören elit düzey bocce sporcularının rekreasyon faaliyetlerine yönelik tatmin ve benlik algısı düzeyleri arasındaki ilişkinin incelenmesidir. Ayrıca üniversite öğrenim gören elit düzey bocce sporcuların rekreasyon faaliyetlerine yönelik tatmin ve benlik algısı düzeylerinin bazı değişkenlere göre incelemiş ve aralarındaki ilişki belirlenmiştir. Bu amaçla aşağıdaki sorulara yanıt aranmaya çalışılmışır: Üniversitede öğrenim gören elit düzey bocce sporcularının;

1. Rekreasyon faaliyetlerine yönelik tatmin ve benlik algısı düzeyleri nasıldır?

2. Rekreasyon faaliyetlerine yönelik tatmin ve benlik algısı düzeyleri; cinsiyet, yaş, günlük serbest zaman süresi ve millilik derecesine göre anlamlı bir farklılık göstermekte midir?

3. Serbest Zaman Tatmin Ölçeği ile Elit Sporcu Benlik Alg1sı Envanteri alt boyutları arasında anlamlı bir ilişki var mıdır?

\section{Yöntem}

Araştırma, nicel araştırma yöntemlerinden ilişkisel tarama modelinde yürütülmüştür. Tarama araştırmaları geçmişte ya da halen var olan bir durumu var olduğu şekliyle betimlemeyi amaçlayan araştırma yaklaşımlarıdır (Karasar, 2008). Fraenkel ve Wallen (2009) tarama araştırmalarının asıl amacının bir gruba ait özelliklerin betimlenmesi olduğunu ifade etmektedir. Korelasyonel olarak da adlandirılan ilişskisel tarama modellerinde ise iki ya da daha fazla değişkenin birlikte değişimi incelenmektedir (Büyüköztürk, Çakmak, Akgün, Karadeniz ve Demirel, 2016).

\section{Evren - Örneklem}

Araştırmaya çeşitli üniversitelerde öğrenim gören, elit düzey bocce sporcuları katılmıştır. Sporcular gönüllü olarak çalışmaya katılmıştır. Katıllımcıların 57 kadın 49 erkek olmak üzere toplam 106 kişiden oluşmaktadır.

\section{Veri Toplama Araçları}

Araştırmada veri toplama aracı olarak demografik özelliklerin belirlenmesi amacıyla kişisel bilgi formu kullanılmıştır. Katılımcıların benlik alg1 düzeylerinin ölçülmesi amacıyla "Elit Sporcu Benlik Algisı Envanteri”" kullanılmıştır. Ayrıca rekreasyon faaliyetlerine yönelik tatmin düzeyinin ölçülmesi amacı için "Serbest Zaman Tatmin Ölçeği” kullanılmıştır.

Elit Sporcu Benlike Algısı Envanteri: Elit Sporcu Benlik Algısı Envanteri ile sporda başarı için gerekli olan fiziksel ve zihinsel uygunluk yetilerinde sporcuların kendilerini algılamalarını değerlendirmektedir. Ölçek niteliği gösteren envanter; Mars vd. (1997) tarafindan geliştirilmiş Çağlar, Aşçı ve Kelecek (2017) tarafından Türkçeye uyarlanarak geçerlik ve güvenirlik çalışması yapılmıştır. Ölçekte algılanan beceri, vücut uygunluğu, aerobik uygunluk, anaerobik uygunluk, zihinsel beceri ve genel performans olmak üzere altı alt boyutta toplanan 29 madde yer almaktadır. Ölçekteki maddeler 6'll Likert $(1=$ Tamamen Yanlış ile $6=$ Tamamen Doğru) tipinde derecelendirilmiştir.

Serbest Zaman Tatmin Ölçeği: Üniversite öğrencilerinin serbest zamanlarını değerlendirme şekillerine yönelik tatmin düzeylerini belirlemek amacıyla Beard ve Ragheb (1980) tarafindan geliştirilen Karlı, Polat, Yılmaz ve Koçak (2008) tarafindan Türkçeye uyarlaması gerçekleştirilen "Serbest Zaman Tatmin Ölçeği" kullanılmıştır. Ölçekte psikolojik, eğitim, sosyal, rahatlama, fizyolojik ve estetik olmak üzere toplam 6 boyutta toplanan 39 madde yer almaktadır. Ölçekteki maddeler 5'li likert tipinde (Benim için hemen hemen hiç geçerli değil - Benim için hemen hemen her zaman geçerli) derecelendirilmiştir. 


\section{Verilerin Analizi}

Verilerin analizinde, SPSS 23.0 paket programı kullanılmıştır. Betimsel istatistik, t-testi, Kruskal Wallis, Pearson Korelasyon katsayısı ile analiz yapılmıştır. Sonuçlar bu analizler ışığında belirlenmiştir.

\section{Bulgular}

Araştırmaya katılan 106 sporcunun demografik özelliklerine göre dağılımları incelenmiştir. Demografik özellileri olarak cinsiyet, yaş günlük serbest zaman ve millilik dereceleri ele alınmıştır. Sonuçlar aşağıda yer almaktadır.

Tablo 1. Katulimcılarn Demografik Değģşkenlere Göre Yü̈de ve Frekans Değerleri

\begin{tabular}{llll}
\hline Değişkenler & \multicolumn{1}{c}{ Kategoriler } & $\boldsymbol{f}$ & $\boldsymbol{\%}$ \\
\hline \multirow{2}{*}{ Cinsiyet } & Kadın & 57 & 53,8 \\
\hline \multirow{2}{*}{ Yaş } & Erkek & 49 & 46,2 \\
\hline \multirow{3}{*}{ Günlük serbest zaman } & 21 yaş ve alt1 & 50 & 47,2 \\
\cline { 2 - 4 } & 21 yaş üstü & 56 & 52,8 \\
\hline \multirow{3}{*}{ Millilik derecesi } & 1-2 saat & 46 & 43,4 \\
\cline { 2 - 4 } & 3-4 saat & 40 & 37,7 \\
\cline { 2 - 4 } & S-6 saat & 20 & 18,9 \\
\cline { 2 - 4 } & B Milli & 15 & 14,2 \\
\cline { 2 - 4 } & C Milli & 35 & 33,0 \\
\hline
\end{tabular}

Tablo 1. incelendiğinde araştırma kapsamında görüşleri alınan bocce sporcularının \% 53,8 ( $\mathrm{n}=57)$ kadın \% 46,2'sinin ( $\mathrm{n}=49)$ erkek olduğu, \% 47,2'sinin ( $\mathrm{n}=50) 21$ yaş ve altında olduğu, \% 52,8’inin $(n=56)$ yaşının 22 ve üzerinde olduğu tespit edilmiştir. Bocce sporcularının \% 43,4'ünün ( $n=46)$ günlük 1 2 saat serbest zamanı bulunduğunu belirttikleri görülmektedir. Sporcuların \% 37,7'sinin ( $\mathrm{n}=40)$ günlük serbest zamanı 3-4 saat iken \% 18,9'unun $(\mathrm{n}=20)$ ise 5-6 saattir. Ayrica sporcularının \% 14,2'si (n=15) A Milli, \% 33,0’ü ( $\mathrm{n}=35)$ B Milli, \% 52,8’i ( $\mathrm{n}=56)$ C Milli derecesine sahiptir.

Tablo 2. Kathlimclarnn Benlik. Algılarmnn Cinsiyet Değģskeenine Göre t-Testi Sonuclar

\begin{tabular}{|c|c|c|c|c|c|c|c|}
\hline Benlik alg1s1 & Cinsiyet & $N$ & $\overline{\boldsymbol{X}}$ & $S S$ & $s d$ & $t$ & $p$ \\
\hline \multirow{2}{*}{ Alg1lanan beceri } & Kadin & 57 & 23,40 & 3,84 & 104 & 1,998 & $0,048^{*}$ \\
\hline & Erkek & 49 & 21,88 & 4,01 & & & \\
\hline \multirow{2}{*}{ Vücut uygunluğu } & Kadin & 57 & 18,60 & 3,57 & 104 & 2,724 & $0,008^{*}$ \\
\hline & Erkek & 49 & 16,59 & 4,01 & & & \\
\hline \multirow{2}{*}{ Aerobik uygunluk } & Kadin & 57 & 18,32 & 2,64 & 104 & 2,617 & $0,010^{*}$ \\
\hline & Erkek & 49 & 16,88 & 3,02 & & & \\
\hline \multirow{2}{*}{ Anaerobik uygunluk } & Kadın & 57 & 22,23 & 3,43 & 104 & 1,718 & 0,089 \\
\hline & Erkek & 49 & 21,08 & 3,42 & & & \\
\hline \multirow{2}{*}{ Zihinsel beceri } & Kadın & 57 & 23,07 & 3,17 & 104 & 1,826 & 0,071 \\
\hline & Erkek & 49 & 21,88 & 3,56 & & & \\
\hline \multirow{2}{*}{ Genel performans } & Kadin & 57 & 27,95 & 4,04 & 104 & 2,208 & $0,029 *$ \\
\hline & Erkek & 49 & 26,14 & 4,37 & & & \\
\hline \multirow{2}{*}{ Benlik alg1s1 (toplam) } & Kadın & 57 & 133,56 & 17,33 & 104 & 2,581 & $0,011^{*}$ \\
\hline & Erkek & 49 & 124,45 & 19,01 & & & \\
\hline
\end{tabular}

${ }^{*} \mathrm{p}<0,05$

Tablo 2 incelendiğinde üniversitelerde öğrenim gören bocce sporcularının cinsiyetlerine göre anaerobik $\left(\mathrm{t}_{(104)}=1,718 ; \mathrm{p}>0,05\right)$ ve zihinsel beceri $\left(\mathrm{t}_{(104)}=1,826 ; \mathrm{p}>0,05\right)$ benlik algilarının anlamlı bir farkllık göstermediği görülmektedir. Sporcuların algılanan beceri $\left(\mathrm{t}_{(104)}=1,998 ; \mathrm{p}<0,05\right)$, vücut uygunluğu $\left(\mathrm{t}_{(104)}=2,724 ; \mathrm{p}<0,05\right)$, aerobik uygunluk $\left(\mathrm{t}_{(104)}=2,617 ; \mathrm{p}<0,05\right)$, genel performans $\left(\mathrm{t}_{(104)}=2,208 ; \mathrm{p}<0,05\right)$ ve genel olarak sporcu benlik algilarının $\left(\mathrm{t}_{(104)}=2,581 ; \mathrm{p}<0,05\right)$ cinsiyetlerine göre anlamlı farklılıklar gösterdiği belirlenmiştir. Ortalama puanlar incelendiğinde kadın sporcuların erkek sporculara göre algılanan beceri, vücut uygunluğu, aerobik uygunluk, genel performans ve sporcu benlik algilarının anlamlı bir şekilde daha yüksek düzeyde olduğu tespit edilmiştir. 
Tablo 3. Katılımcılarn Serbest Zaman Tatmin Düzeylerinin Cinsiyet Değişkenine Göre t-Testi Sonuclar

\begin{tabular}{|c|c|c|c|c|c|c|c|}
\hline Serbest zaman tatmini & Cinsiyet & $N$ & $\overline{\boldsymbol{X}}$ & $S S$ & $s d$ & $t$ & $p$ \\
\hline \multirow{2}{*}{ Eğitim } & Kadin & 57 & 39,14 & 4,00 & 104 & 1,093 & 0,277 \\
\hline & Erkek & 49 & 38,16 & 5,19 & & & \\
\hline \multirow{2}{*}{ Fizyolojik } & Kadın & 57 & 25,12 & 3,13 & 104 & 0,032 & 0,975 \\
\hline & Erkek & 49 & 25,14 & 3,41 & & & \\
\hline \multirow{2}{*}{ Estetik } & Kadin & 57 & 16,89 & 1,83 & 104 & 0,102 & 0,919 \\
\hline & Erkek & 49 & 16,94 & 2,60 & & & \\
\hline \multirow{2}{*}{ Rahatlama } & Kadın & 57 & 17,37 & 2,26 & 104 & 0,921 & 0,359 \\
\hline & Erkek & 49 & 16,88 & 3,21 & & & \\
\hline \multirow{2}{*}{ Sosyal } & Kadın & 57 & 34,18 & 4,36 & 104 & 0,643 & 0,522 \\
\hline & Erkek & 49 & 34,76 & 4,93 & & & \\
\hline \multirow{2}{*}{ Psikolojik } & Kadın & 57 & 34,30 & 4,38 & 104 & 2,004 & $0,048^{*}$ \\
\hline & Erkek & 49 & 32,39 & 5,43 & & & \\
\hline \multirow{2}{*}{ Serbest zaman tatmini (toplam) } & Kadın & 57 & 167,00 & 17,19 & 104 & 0,899 & 0,371 \\
\hline & Erkek & 49 & 163,45 & 23,37 & & & \\
\hline
\end{tabular}
${ }^{*} \mathrm{p}<0,05$

Tablo 3 incelendiğinde üniversitelerde öğrenim gören bocce sporcularının cinsiyetlerine göre eğitim $\left(\mathrm{t}_{(104)}=1,093 ; \mathrm{p}>0,05\right)$, fizyolojik $\left(\mathrm{t}_{(104)}=0,032 ; \mathrm{p}>0,05\right)$, estetik $\quad\left(\mathrm{t}_{(104)}=0,102 ; \mathrm{p}>0,05\right)$, rahatlama $\left(\mathrm{t}_{(104)}=0,921 ; \mathrm{p}>0,05\right)$, sosyal $\quad\left(\mathrm{t}_{(104)}=0,643 ; \mathrm{p}>0,05\right)$ tatminlerinin ve genel olarak serbest zaman tatminlerinin $\left(\mathrm{t}_{(104)}=0,899 ; \mathrm{p}>0,05\right)$ anlamlı bir farkllılı göstermediği tespit edilmiştir. Bununla beraber sporcuların serbest zamanlardaki psikolojik tatminlerinin cinsiyetlerine göre anlamlı bir değişiklik düzeyi gösterdiği belirlenmiştir $\left(\mathrm{t}_{(104)}=2,004 ; \mathrm{p}<0,05\right)$. Ortalama puanlar incelendiğinde kadın sporcuların $(34,30 \pm 4,38)$, erkek sporculara $(32,39 \pm 5,43)$ göre psikolojik tatminlerinin daha yüksek düzeyde olduğu saptanmiştır.

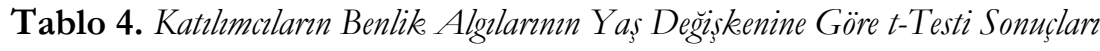

\begin{tabular}{|c|c|c|c|c|c|c|c|}
\hline Benlik alg1s1 & Yaş & $N$ & $\bar{X}$ & $S S$ & $s d$ & $t$ & $p$ \\
\hline \multirow{2}{*}{ Algilanan beceri } & 21 yaş ve altı & 50 & 21,84 & 4,03 & 104 & 2,135 & $0,035^{*}$ \\
\hline & 21 yaş üstü & 56 & 23,46 & 3,80 & & & \\
\hline \multirow{2}{*}{ Vücut uygunluğu } & 21 yaş ve altı & 50 & 16,56 & 3,91 & 104 & 2,869 & $0,005^{*}$ \\
\hline & 21 yaş üstü & 56 & 18,66 & 3,63 & & & \\
\hline \multirow{2}{*}{ Aerobik uygunluk } & 21 yaş ve altı & 50 & 17,12 & 2,54 & 104 & 1,801 & 0,075 \\
\hline & 21 yaş üstü & 56 & 18,13 & 3,13 & & & \\
\hline \multirow{2}{*}{ Anaerobik uygunluk } & 21 yaş ve altı & 50 & 20,84 & 3,64 & 104 & 2,473 & $0,015^{*}$ \\
\hline & 21 yaş üstü & 56 & 22,46 & 3,12 & & & \\
\hline \multirow{2}{*}{ Zihinsel beceri } & 21 yaş ve altı & 50 & 21,84 & 3,48 & 104 & 1,975 & 0,051 \\
\hline & 21 yaş üstü & 56 & 23,13 & 3,21 & & & \\
\hline \multirow{2}{*}{ Genel performans } & 21 yaş ve altı & 50 & 25,96 & 4,56 & 104 & 2,704 & $0,008^{*}$ \\
\hline & 21 yaş üstü & 56 & 28,14 & 3,75 & & & \\
\hline \multirow{2}{*}{ Benlik alg1s1 (toplam) } & 21 yaş ve altı & 50 & 124,16 & 18,79 & 104 & 2,800 & $0,006^{*}$ \\
\hline & 21 yaş üstü & 56 & 133,98 & 17,32 & & & \\
\hline
\end{tabular}

${ }^{*} \mathrm{p}<0,05$

Tablo 4'de yer alan bilgiler incelendiğinde sporcuların yaşlarına göre aerobik uygunluk $\left(\mathrm{t}_{(104)}=1,801\right.$; $\mathrm{p}>0,05)$ ve zihinsel beceri $\left(\mathrm{t}_{(104)}=1,975 ; \mathrm{p}>0,05\right)$ benlik algılarının anlamlı bir değişiklik göstermediği belirlenmiştir. Üniversitelerde öğrenim gören bocce sporcularının yaşlarına göre algıllanan beceri $\left(\mathrm{t}_{(104)}=2,135 ; \mathrm{p}<0,05\right)$, vücut uygunluğu $\left(\mathrm{t}_{(104)}=2,869 ; \mathrm{p}<0,05\right)$, anaerobik uygunluk $\left(\mathrm{t}_{(104)}=2,473 ; \mathrm{p}<0,05\right)$, genel performans $\left(\mathrm{t}_{(104)}=2,704 ; \mathrm{p}<0,05\right)$ ve genel olarak sporcu benlik algilarının $\left(\mathrm{t}_{(104)}=2,800 ; \mathrm{p}<0,05\right)$ ise anlamlı farklılıklar gösterdiği saptanmıştır. Ortalama puanlar incelendiğinde 21 yaşın üzerindeki sporcuların 21 yaş ve altındakilere göre söz konusu sporcu benlik algılarının anlamlı bir şekilde daha yüksek olduğu tespit edilmiştir. 
YAŞARTÜRK ve AYDIN

Üniversitede Öğrenim Gören Elit Düzey Bocce Sporcularının Rekreasyon Faaliyetlerine Yönelik Tatmin ve Benlik Algısı Düzeyleri Arasındaki İlişkinin Incelenmesi

Tablo 5. Katılimcularn Serbest Zaman Tatmin Düzeylerinin Yas Değişkenine Göre t-Testi Sonuçları

\begin{tabular}{|c|c|c|c|c|c|c|c|}
\hline Serbest zaman tatmini & Yass & $N$ & $\bar{X}$ & $S S$ & $s d$ & $t$ & $p$ \\
\hline \multirow{2}{*}{ Eğitim } & 21 yaş ve altı & 50 & 38,28 & 4,69 & 104 & 0,865 & 0,389 \\
\hline & 21 yaş üstü & 56 & 39,05 & 4,52 & & & \\
\hline \multirow{2}{*}{ Fizyolojik } & 21 yaş ve altı & 50 & 24,52 & 3,43 & 104 & 1,856 & 0,066 \\
\hline & 21 yaş üstü & 56 & 25,68 & 3,00 & & & \\
\hline \multirow{2}{*}{ Estetik } & 21 yaş ve altı & 50 & 16,84 & 2,61 & 104 & 0,329 & 0,743 \\
\hline & 21 yaş üstü & 56 & 16,98 & 1,80 & & & \\
\hline \multirow{2}{*}{ Rahatlama } & 21 yaş ve altı & 50 & 16,78 & 3,19 & 104 & 1,290 & 0,200 \\
\hline & 21 yaş üstü & 56 & 17,46 & 2,23 & & & \\
\hline \multirow{2}{*}{ Sosyal } & 21 yaş ve altı & 50 & 34,10 & 5,40 & 104 & 0,722 & 0,472 \\
\hline & 21 yaş üstü & 56 & 34,75 & 3,80 & & & \\
\hline \multirow{2}{*}{ Psikolojik } & 21 yaş ve altı & 50 & 32,82 & 4,85 & 104 & 1,169 & 0,245 \\
\hline & 21 yaş üstü & 56 & 33,95 & 5,05 & & & \\
\hline \multirow{2}{*}{$\begin{array}{l}\text { Serbest zaman tatmini } \\
\text { (toplam) }\end{array}$} & 21 yaş ve altı & 50 & 162,54 & 23,44 & 104 & 1,359 & 0,177 \\
\hline & 21 yaş üstü & 56 & 167,88 & 16,75 & & & \\
\hline
\end{tabular}

$*_{\mathrm{p}}<0,05$

Tablo 5'de görüldüğü gibi üniversitelerde öğrenim gören bocce sporcularının eğitim $\left(\mathrm{t}_{(104)}=0,865\right.$; $\mathrm{p}>0,05)$, fizyolojik $\left(\mathrm{t}_{(104)}=1,856 ; \mathrm{p}>0,05\right)$, estetik $\left(\mathrm{t}_{(104)}=0,329 ; \mathrm{p}>0,05\right)$, rahatlama $\left(\mathrm{t}_{(104)}=1,290 ; \mathrm{p}>0,05\right)$, sosyal $\left(\mathrm{t}_{(104)}=0,722 ; \mathrm{p}>0,05\right)$, psikolojik $\left(\mathrm{t}_{(104)}=1,169 ; \mathrm{p}>0,05\right)$ tatminlerinin ve genel olarak serbest zaman tatminlerinin $\left(\mathrm{t}_{(104)}=1,359 ; \mathrm{p}>0,05\right)$ anlamlı bir farklılık göstermediği belirlenmiştir. Başka bir ifadeyle 21 yaş ve altındaki sporcularla 21 yaşın üstündeki sporcuların serbest zaman tatminlerinin hem alt boyutlarda hem de genel olarak benzerlik gösterdiği tespit edilmiştir.

Tablo 6. Katılımolarn Benlik. Algılarmm Günlük Serbest Zamanlarna Göre Hesaplanan Kruskal Wallis Testi Sonuçlar

\begin{tabular}{|c|c|c|c|c|c|c|}
\hline Ölçek & Günlük serbest zaman & $N$ & Sira $\bar{X}$ & $X^{2}$ & $s d$ & $p$ \\
\hline \multirow{3}{*}{ Alg1lanan beceri } & $1-2$ saat & 46 & 46,02 & 9,142 & 2 & $0,010^{*}$ \\
\hline & 3-4 saat & 40 & 53,51 & & & \\
\hline & 5-6 saat & 20 & 70,68 & & & \\
\hline \multirow{3}{*}{ Vücut uygunluğu } & $1-2$ saat & 46 & 41,58 & 19,280 & 2 & $0,000^{*}$ \\
\hline & 3-4 saat & 40 & 55,89 & & & \\
\hline & 5-6 saat & 20 & 76,15 & & & \\
\hline \multirow{3}{*}{ Aerobik uygunluk } & $1-2$ saat & 46 & 47,33 & 3,499 & 2 & 0,174 \\
\hline & 3-4 saat & 40 & 59,36 & & & \\
\hline & 5-6 saat & 20 & 55,98 & & & \\
\hline \multirow{3}{*}{ Anaerobik uygunluk } & $1-2$ saat & 46 & 45,33 & 5,960 & 2 & 0,051 \\
\hline & 3-4 saat & 40 & 58,78 & & & \\
\hline & 5-6 saat & 20 & 61,75 & & & \\
\hline \multirow{3}{*}{ Zihinsel beceri } & 1-2 saat & 46 & 47,90 & 13,803 & 2 & $0,001 *$ \\
\hline & 3-4 saat & 40 & 48,60 & & & \\
\hline & 5-6 saat & 20 & 76,18 & & & \\
\hline \multirow{3}{*}{ Genel performans } & $1-2$ saat & 46 & 49,67 & 16,144 & 2 & $0,000^{*}$ \\
\hline & 3-4 saat & 40 & 45,73 & & & \\
\hline & 5-6 saat & 20 & 77,85 & & & \\
\hline \multirow{3}{*}{ Benlik alg1s1 (toplam) } & $1-2$ saat & 46 & 45,14 & 10,911 & 2 & $0,004 *$ \\
\hline & 3-4 saat & 40 & 53,70 & & & \\
\hline & 5-6 saat & 20 & 72,33 & & & \\
\hline
\end{tabular}

${ }^{*} \mathrm{p}<0,05$

Tablo 6'da yer alan bilgiler incelendiğinde sporcuların günlük serbest zamanlarına göre aerobik uygunluklarının $\left(\mathrm{X}_{(2)}=3,499 ; \mathrm{p}>0,05\right)$, anaerobik uygunluklarının $\left(\mathrm{X}_{(2)}^{2}=5,960 ; \mathrm{p}>0,05\right)$ anlamlı bir farklılık göstermediği tespit edilmiştir. Diğer bir ifadeyle günlük serbest zamanı 1-2 saat, 3-4 saat, 5-6 saat olan sporcuların aerobik ve anaerobik uygunluklarına yönelik algılarının benzerlik gösterdiği belirlenmiştir. Bocce sporcularının algıladıkları becerilerinin $\left(X^{2}{ }_{(2)}=9,142 ; \mathrm{p}<0,05\right)$, vücut uygunluklarının $\left(X^{2}{ }_{(2)}=19,280\right.$; $\mathrm{p}<0,05)$, zihinsel becerilerinin $\left(\mathrm{X}_{(2)}=13,803 ; \mathrm{p}<0,05\right)$, genel performanslarını $\left(\mathrm{X}_{(2)}=16,144 ; \mathrm{p}<0,05\right)$ ve genel sporcu benlik algılarının $\left(\mathrm{X}_{(2)}^{2}=10,911 ; \mathrm{p}<0,05\right)$ günlük serbest zamanlarına göre anlamlı bir 
değişiklik gösterdiği tespit edilmiştir. Hesaplama sonucunda günlük serbest zamanı 5-6 saat olan sporcuların sporcu benlik algilarını $(140,65 \pm 9,34)$; serbest zamanı $1-2$ saat $(124,83 \pm 20,08)$ ve $3-4$ saat $(128,90 \pm 18,28)$ olan sporculardan anlamlı bir şekilde daha yüksek düzeyde olduğu tespit edilmiştir.

Tablo 7. Katılımcılarn Serbest Zaman Tatminlerinin Günlük Serbest Zamanlarna Göre Hesaplanan Kruskal Wallis Testi Sonuclar

\begin{tabular}{|c|c|c|c|c|c|c|}
\hline Serbest zaman tatminleri & Günlük serbest zaman & $N$ & Sira $\bar{X}$ & $X^{2}$ & $s d$ & $p$ \\
\hline \multirow{3}{*}{ Eğitim } & $1-2$ saat & 46 & 53,14 & 0,156 & 2 & 0,925 \\
\hline & $3-4$ saat & 40 & 52,71 & & & \\
\hline & 5-6 saat & 20 & 55,90 & & & \\
\hline \multirow{3}{*}{ Fizyolojik } & $1-2$ saat & 46 & 50,38 & 3,695 & 2 & 0,158 \\
\hline & 3-4 saat & 40 & 60,58 & & & \\
\hline & 5-6 saat & 20 & 46,53 & & & \\
\hline \multirow{3}{*}{ Estetik } & $1-2$ saat & 46 & 53,34 & 0,002 & 2 & 0,999 \\
\hline & 3-4 saat & 40 & 53,61 & & & \\
\hline & 5-6 saat & 20 & 53,65 & & & \\
\hline \multirow{3}{*}{ Rahatlama } & $1-2$ saat & 46 & 52,30 & 0,881 & 2 & 0,644 \\
\hline & $3-4$ saat & 40 & 52,03 & & & \\
\hline & 5-6 saat & 20 & 59,20 & & & \\
\hline \multirow{3}{*}{ Sosyal } & 1-2 saat & 46 & 50,82 & 0,737 & 2 & 0,692 \\
\hline & 3-4 saat & 40 & 56,49 & & & \\
\hline & 5-6 saat & 20 & 53,70 & & & \\
\hline \multirow{3}{*}{ Psikolojik } & 1-2 saat & 46 & 49,04 & 1,753 & 2 & 0,416 \\
\hline & 3-4 saat & 40 & 57,45 & & & \\
\hline & 5-6 saat & 20 & 55,85 & & & \\
\hline \multirow{3}{*}{$\begin{array}{l}\text { Serbest zaman tatmini } \\
\text { (toplam) }\end{array}$} & 1-2 saat & 46 & 51,58 & 0,424 & 2 & 0,809 \\
\hline & 3-4 saat & 40 & 55,89 & & & \\
\hline & 5-6 saat & 20 & 53,15 & & & \\
\hline
\end{tabular}

$*_{\mathrm{p}}<0,05$

Tablo 7'de görüldüğü gibi üniversitede öğrenim gören bocce sporcularının eğitim $\left(\mathrm{X}^{2}(2)=0,156\right.$; $\mathrm{p}>0,05)$, fizyolojik $\left(\mathrm{X}_{(2)}=3,695 ; \mathrm{p}>0,05\right)$, estetik $\left(\mathrm{X}_{(2)}=0,002 ; \mathrm{p}>0,05\right)$, rahatlama $\left(\mathrm{X}_{(2)}=0,881 ; \mathrm{p}>0,05\right)$, sosyal $\left(\mathrm{X}^{2}{ }_{(2)}=0,737 ; \mathrm{p}>0,05\right)$ ve psikolojik $\left(\mathrm{X}_{(2)}=1,753 ; \mathrm{p}>0,05\right)$ tatminleri günlük serbest zamanlarına göre anlamlı bir farklılık göstermemektedir. Benzer şekilde sporcuların günlük serbest zamanlarına göre serbest zaman tatminlerinin anlamlı bir değişiklik göstermediği belirlenmiştir $\left(\mathrm{X}_{(2)}{ }_{(2)}=0,424 ; \mathrm{p}>0,05\right)$. Başka bir anlatımla günlük serbest zamanı 1-2 saat, 3-4 saat, 5-6 saat olan sporcuların serbest zaman tatminlerinin genel olarak ve tüm alt boyutlarda benzerlik gösterdiği tespit edilmiştir.

Tablo 8. Katılımcılarn Benlik. Algılarmın Millilik Derecelerine Göre Hesaplanan Kruskal Wallis Testi Sonuçları

\begin{tabular}{|c|c|c|c|c|c|c|}
\hline Benlik algılant & Sporculuk süresi & $N$ & Sira $\bar{X}$ & $X^{2}$ & $s d$ & $p$ \\
\hline \multirow{3}{*}{ Alg1lanan beceri } & A Milli & 15 & 60,03 & 11,461 & 2 & $0,003^{*}$ \\
\hline & B Milli & 35 & 65,60 & & & \\
\hline & C Milli & 56 & 44,19 & & & \\
\hline \multirow{3}{*}{ Vücut uygunluğu } & A Milli & 15 & 57,43 & 5,528 & 2 & 0,063 \\
\hline & B Milli & 35 & 61,86 & & & \\
\hline & C Milli & 56 & 47,22 & & & \\
\hline \multirow{3}{*}{ Aerobik uygunluk } & A Milli & 15 & 62,97 & 1,875 & 2 & 0,392 \\
\hline & B Milli & 35 & 53,70 & & & \\
\hline & C Milli & 56 & 50,84 & & & \\
\hline \multirow{3}{*}{ Anaerobik uygunluk } & A Milli & 15 & 65,10 & 4,287 & 2 & 0,117 \\
\hline & B Milli & 35 & 56,96 & & & \\
\hline & C Milli & 56 & 48,23 & & & \\
\hline \multirow{3}{*}{ Zihinsel beceri } & A Milli & 15 & 61,67 & 12,600 & 2 & $0,002 *$ \\
\hline & B Milli & 35 & 65,69 & & & \\
\hline & C Milli & 56 & 43,70 & & & \\
\hline \multirow{3}{*}{ Genel performans } & A Milli & 15 & 57,97 & 12,600 & 2 & $0,002 *$ \\
\hline & B Milli & 35 & 66,87 & & & \\
\hline & C Milli & 56 & 43,95 & & & \\
\hline \multirow{3}{*}{ Benlik algıs1 (toplam) } & A Milli & 15 & 62,93 & 7,650 & 2 & $0,022^{*}$ \\
\hline & B Milli & 35 & 61,93 & & & \\
\hline & C Milli & 56 & 45,71 & & & \\
\hline
\end{tabular}


Tablo 8'de yer alan bilgiler incelendiğinde bocce sporcularının millilik derecesine göre vücut uygunluklarını $\left(\mathrm{X}_{(2)}=5,528 ; \mathrm{p}>0,05\right)$, aerobik uygunluklarının $\left(\mathrm{X}_{(2)}=1,875 ; \mathrm{p}>0,05\right)$ ve anaerobik uygunluklarının $\left(\mathrm{X}_{(2)}^{2}=4,287 ; \mathrm{p}>0,05\right)$ anlamlı bir değişiklik göstermediği görülmektedir. Diğer bir ifadeyle A milli, B milli ve C milli takımında oynayan sporcuların vücut, aerobik ve anaerobik uygunluklarına yönelik algılarının benzerlik gösterdiği tespit edilmiştir.

Bocce sporcularının algiladıkları becerilerinin $\left(\mathrm{X}_{(2)}^{2}=11,461 ; \mathrm{p}<0,05\right)$, zihinsel becerilerinin $\left(X^{2}{ }_{(2)}=12,600 ; p<0,05\right)$, genel performanslarının $\left(X^{2}{ }_{(2)}=12,600 ; p<0,05\right)$ ve genel olarak benlik algilarının $\left(\mathrm{X}^{2}(2)=7,650 ; \mathrm{p}<0,05\right)$ anlamlı bir farklılık gösterdiği tespit edilmiştir. Hesaplama sonucunda $\mathrm{B}$ millide olan sporcuların alg1ladıkları becerilerinin $(24,34 \pm 2,50)$, C millide olan sporculardan $(21,43 \pm 4,31)$ anlamlı bir şekilde daha yüksek olduğu belirlenmiştir. C millide olan sporcuların zihinsel beceri algılarının $(21,34 \pm 3,44)$; A millide oynayan $(23,67 \pm 2,16)$ ve B milli derecesine sahip sporculardan $(23,91 \pm 3,09)$ anlamlı bir şekilde daha düşük olduğu tespit edilmiştir. C milli derecesine sahip bocce sporcularının genel performans alg1larının $(25,68 \pm 4,25)$ B milli derecesine sahip sporculardan $(29,00 \pm 3,84)$ anlamlı bir şekilde daha düşük olduğu belirlenmiştir. Benzer şekilde $\mathrm{C}$ millideki bocce sporcularının genel olarak benlik alg1larının $(123,88 \pm 19,84)$ B millideki sporculardan $(135,69 \pm 13,00)$ anlamlı bir şekilde daha düşük olduğu tespit edilmiştir.

Tablo 9. Katıllmallarn Serbest Zaman Tatminlerinin Millilik. Derecelerine Göre Hesaplanan Kruskal Wallis Testi Sonuçları

\begin{tabular}{|c|c|c|c|c|c|c|}
\hline $\begin{array}{l}\text { Serbest zaman } \\
\text { tatminleri }\end{array}$ & Sporculuk süresi & $N$ & Sira $\bar{X}$ & $X^{2}$ & $s d$ & $p$ \\
\hline \multirow{3}{*}{ Fizyolojik } & A Milli & 15 & 57,73 & 12,437 & 2 & $0,002^{*}$ \\
\hline & B Milli & 35 & 66,93 & & & \\
\hline & C Milli & 56 & 43,97 & & & \\
\hline \multirow{3}{*}{ Fizyolojik } & A Milli & 15 & 67,40 & 6,718 & 2 & $0,035^{*}$ \\
\hline & B Milli & 35 & 58,29 & & & \\
\hline & C Milli & 56 & 46,79 & & & \\
\hline \multirow{3}{*}{ Estetik } & A Milli & 15 & 63,07 & 20,380 & 2 & $0,000^{*}$ \\
\hline & B Milli & 35 & 69,04 & & & \\
\hline & C Milli & 56 & 41,22 & & & \\
\hline \multirow{3}{*}{ Rahatlama } & A Milli & 15 & 62,90 & 20,354 & 2 & $0,000^{*}$ \\
\hline & B Milli & 35 & 69,24 & & & \\
\hline & C Milli & 56 & 41,14 & & & \\
\hline \multirow{3}{*}{ Sosyal } & A Milli & 15 & 61,67 & 13,172 & 2 & $0,001^{*}$ \\
\hline & B Milli & 35 & 66,16 & & & \\
\hline & C Milli & 56 & 43,40 & & & \\
\hline \multirow{3}{*}{ Psikolojik } & A Milli & 15 & 62,83 & 5,698 & 2 & 0,058 \\
\hline & B Milli & 35 & 60,17 & & & \\
\hline & C Milli & 56 & 46,83 & & & \\
\hline \multirow{3}{*}{$\begin{array}{l}\text { Serbest zaman tatmini } \\
\text { (toplam) }\end{array}$} & A Milli & 15 & 62,93 & 12,550 & 2 & $0,002^{*}$ \\
\hline & B Milli & 35 & 65,40 & & & \\
\hline & C Milli & 56 & 43,54 & & & \\
\hline
\end{tabular}

${ }^{*} \mathrm{p}<0,05$

Tablo 9 incelendiğinde bocce sporcularının millilik derecesine göre psikolojik tatminlerinin anlamlı olarak farklılık yaratmadığı belirlenmiştir $\left(\mathrm{X}_{(2)}=5,698 ; \mathrm{p}>0,05\right)$. Farklı bir şekilde ifade etmek gerekirse A milli, B milli ve C milli takımında oynayan sporcuların psikolojik tatminlerinin benzerlik gösterdiği tespit edilmiştir. Üniversitelerde öğrenim gören bocce sporcularının eğitim $\left(\mathrm{X}^{2}(2)=12,437 ; \mathrm{p}<0,05\right)$, fizyolojik $\left(\mathrm{X}_{(2)}^{2}=6,718 ; \mathrm{p}<0,05\right)$, estetik $\left(\mathrm{X}_{(2)}^{2}=20,380 ; \mathrm{p}<0,05\right)$, rahatlama $\left(\mathrm{X}_{(2)}^{2}=20,354 ; \mathrm{p}<0,05\right)$, sosyal $\left(\mathrm{X}^{2}{ }_{(2)}=13,172 ; \mathrm{p}<0,05\right)$ tatminlerinin ve genel olarak serbest zaman tatminlerinin $\left(\mathrm{X}^{2}{ }_{(2)}=12,550 ; \mathrm{p}<0,05\right)$ sporcuların millililik derecesine göre anlamlı bir değişiklik gösterdiği belirlenmiştir. Hesaplama sonucunda $\mathrm{B}$ milli derecesine sahip sporcuların eğitim tatminlerinin $(40,74 \pm 3,05), C$ milli derecesindeki sporculardan $(37,29 \pm 4,72)$ anlamlı bir şekilde daha yüksek olduğu belirlenmiştir. A milli derecesine sahip bocce sporcularının fizyolojik tatminlerinin $(26,40 \pm 3,74)$, C milli derecesindeki sporculardan $(24,36 \pm 3,45)$ anlamlı bir biçimde daha yüksek olduğu bulunmuştur. C milli bocce sporcularının estetik tatminlerinin $(16,02 \pm 2,14)$, A milli $(17,67 \pm 2,19)$ ve B milli $(18,03 \pm 1,67)$ sporcularından anlamlı bir şekilde daha düşük olduğu tespit edilmiştir. Benzer şekilde $C$ milli bocce sporcularının rahatlama tatminlerinin $(16,04 \pm 2,81)$, A milli $(18,07 \pm 2,09)$ ve $\mathrm{B}$ milli $(18,51 \pm 2,05)$ sporcularından anlamlı bir şekilde daha düşük olduğu 
saptanmıştır. B milli derecesine sahip bocce sporcularının sosyal tatminlerinin $(36,54 \pm 2,96)$, C milli derecesindeki sporculardan $(32,82 \pm 4,98)$ anlamlı bir şekilde daha yüksek olduğu belirlenmiştir. Benzer şekilde B milli derecesine sahip bocce sporcularının serbest zaman tatminlerinin $(174,20 \pm 11,36)$, C milli derecesindeki sporculardan $(158,11 \pm 22,13)$ anlamlı bir biçimde daha yüksek olduğu bulunmuştur.

Araştırmaya katılan üniversite öğrenim gören bocce sporcularının sporcu benlik algıları ile serbest zaman tatminleri arasındaki ilişkinin belirlenmesi amacıyla Pearson korelasyon katsayısı hesaplanmıştır. Bu hesaplamada ESBAE ve SZTÖ alt boyutlar açısından da karşılaştırılmıştır. Sonuçlar Tablo 10'da gösterilmiştir.

Tablo 10. Katılimclarn Benlik. Algularn İle Serbest Zaman Tatminleri Arasındaki İliski Düzeyleri

\begin{tabular}{lcccccccc}
\hline Benlik alg1lart & Değerler & Eğitim & Fizyolojik & Estetik & Rahatlama & Sosyal & Psikolojik & $\begin{array}{c}\text { Serbest zaman } \\
\text { (toplam) }\end{array}$ \\
\hline Alg1lanan beceri & $\mathrm{r}$ &, $557^{* *}$ &, $460^{* *}$ &, $421^{* *}$ &, $544^{* *}$ &, $483^{* *}$ &, $493^{* *}$ &, $576^{* *}$ \\
& $\mathrm{p}$ &, 000 &, 000 &, 000 &, 000 &, 000 &, 000 &, 000 \\
\hline Vücut & $\mathrm{r}$ &, $552^{* *}$ &, $454^{* *}$ &, $450^{* *}$ &, $617^{* *}$ &, $509^{* *}$ &, $494^{* *}$ &, $594^{* *}$ \\
uygunluğu & $\mathrm{p}$ &, 000 &, 000 &, 000 &, 000 &, 000 &, 000 &, 000 \\
\hline Aerobik & $\mathrm{r}$ &, $356^{* *}$ &, $405^{* *}$ &, $371^{* *}$ &, $368^{* *}$ &, $268^{* *}$ &, $354^{* *}$ &, $405^{* *}$ \\
uygunluk & $\mathrm{p}$ &, 000 &, 000 &, 000 &, 000 &, 005 &, 000 &, 000 \\
\hline Anaerobik & $\mathrm{r}$ &, $483^{* *}$ &, $458^{* *}$ &, $433^{* *}$ &, $453^{* *}$ &, $376^{* *}$ &, $436^{* *}$ &, $508^{* *}$ \\
uygunluk & $\mathrm{p}$ &, 000 &, 000 &, 000 &, 000 &, 000 &, 000 &, 000 \\
\hline Zihinsel beceri & $\mathrm{r}$ &, $466^{* *}$ &, $362^{* *}$ &, $300^{* *}$ &, $387^{* *}$ &, $350^{* *}$ &, $332^{* *}$ &, $429^{* *}$ \\
& $\mathrm{p}$ &, 000 &, 000 &, 002 &, 000 &, 000 &, 001 &, 000 \\
\hline Genel & $\mathrm{r}$ &, $451^{* *}$ &, $459^{* *}$ &, $433^{* *}$ &, $473^{* *}$ &, $430^{* *}$ &, $379^{* *}$ &, $502^{* *}$ \\
performans & $\mathrm{p}$ &, 000 &, 000 &, 000 &, 000 &, 000 &, 000 &, 000 \\
\hline Benlik algis1 & $\mathrm{r}$ &, $568^{* *}$ &, $513^{* *}$ &, $476^{* *}$ &, $566^{* *}$ &, $484^{* *}$ &, $492^{* *}$ &, $598^{* *}$ \\
(toplam) & $\mathrm{p}$ &, 000 &, 000 &, 000 &, 000 &, 000 &, 000 &, 000 \\
\hline
\end{tabular}

${ }^{*} \mathrm{p}<0,05 ;{ }^{* *} \mathrm{p}<0,01$

Tablo 10'da ESBAE ve SZTÖ arasındaki ilişki incelenmiştir. Bu inceleme ölçek alt boyutlarını da içermektedir. Tabloda yer alan bilgiler incelendiğinde üniversitede öğrenim gören bocce sporcularının benlik algıları ile serbest zaman tatminleri arasında pozitif olarak ve orta seviyede bir ilişki olduğu belirlenmiştir $(r=0,598 ; \mathrm{p} .<0,01)$.

\section{Tartışma, Sonuç ve Öneriler}

Cinsiyet değişkenine göre katılımcıların ESBAE alt boyutlarından, anaerobik $(\mathrm{p}>0,05)$ ve zihinsel beceri $(p>0,05)$ benlik algılarının anlamlı bir farklılık göstermediği görülmektedir. Sporcuların algılanan beceri $(p<0,05)$, vücut uygunluğu $(p<0,05)$, aerobik uygunluk $(p<0,05)$, genel performans $(p<0,05)$ ve genel olarak sporcu benlik algılarının $(\mathrm{p}<0,05)$ cinsiyetlerine göre anlamlı farklılıklar gösterdiği belirlenmiştir. Ortalama puanlar incelendiğinde kadın sporcuların erkek sporculara göre algılanan beceri, vücut uygunluğu, aerobik uygunluk, genel performans ve sporcu benlik algilarının anlamlı bir şekilde daha yüksek düzeyde olduğu tespit edilmiştir. Ildız (2014) tarafindan yapılan çalışmada erkek ve kızların fiziksel benlik algısı alt boyutlarından spor yeteneği alt boyutu, fiziksel kondisyon, genel fiziksel yeterlilik ve kuvvet oranlarında $(p<0,001)$ düzeyinde, vücut çekiciliği oranlarında ise $(p<0,05)$ düzeyinde anlamlı fark bulunmuştur. Bu sonuçlar yaptığımız çalş̧mayla paralellik göstermektedir. Bu alanda Pehlivan (2010) tarafindan yapılmış bir diğer çalışmada ise erkek katılımcılar bayan katılımcılardan daha çok puan aldığı görülmüştür. Coşkun ve Altay (2009) tarafından yapılan çalışmaya göre cinsiyet değişkenine göre ögrencilerin benlik algılamaları arasında anlamlı bir farklılığın olmadığ1 görülmüştür. Bu sonuçlar da yaptığımız çalışma ile tezat oluşturmaktadır. Cinsiyetlerine göre SZTÖ alt boyutları incelendiğinde üniversitelerde öğrenim gören bocce sporcularının eğitim ( $p>0,05)$, fizyolojik ( $p>0,05)$, estetik ( $>00,05)$, rahatlama $(p>0,05)$, sosyal $(p>0,05)$ tatminlerinin ve genel olarak serbest zaman tatminlerinin $(p>0,05)$ anlamlı bir farklılık göstermediği tespit edilmiştir. Yiğit (2018), Gökçe (2015) ve Huang (2003), yapılan çalışmalarda cinsiyet değişkeni açısından katılımcıların serbest zaman tatmin düzeyleri arasında anlamlı bir fark bulunamamıştır. Bu sonuçlar bizim çalışmamızla örtüşmektedir. Fakat Serdar (2016) ve Çakır (2017) tarafından yapılan çalışmalarda da kadın öğrenciler, erkek öğrencilerden anlamlı bir şekilde yüksek bulunmuş, Yaman (2016) tarafindan yapılan bir diğer çalışmada ise eğitim ve rahatlama alt boyutlarında 
kadınların erkeklerden yüksek olduğu sonucuna ulaşılmıştır. Araştırma grubumuzda yer alan kadın ve erkek katılımcıların cinsiyetlerinin serbest zaman tatminleri üzerinde bir etkiye sahip olmadığını söyleyebiliriz.

Sporcuların yaş değişkenine göre ESBAE alt boyutları incelendiğinde aerobik uygunluk $(p>0,05)$ ve zihinsel beceri $(p>0,05)$ benlik algılarının anlamlı bir değişiklik göstermediği belirlenmiştir. Üniversitelerde öğrenim gören bocce sporcularının yaşlarına göre algılanan beceri $(p<0,05)$, vücut uygunluğu $(p<0,05)$, anaerobik uygunluk $(p<0,05)$, genel performans $(p<0,05)$ ve genel olarak sporcu benlik algilarının $(p<0,05)$ ise anlamlı farklılıklar gösterdiği saptanmıştır. Ortalama puanlar incelendiğinde 21 yaşın üzerindeki sporcuların 21 yaş ve altındakilere göre söz konusu sporcu benlik algılarının anlamlı bir şekilde daha yüksek olduğu tespit edilmiştir. Bunun sebebini yaşın ilerlemesiyle birlikte kişinin kendini kabullene ve karakterin oturmasına bağlayabiliriz. Böylece kişi kendinin daha çok farkına varmakta ve benlik algısı daha yüksek olmaktadır. SZTÖ alt boyutları yaş değişkenine göre eğitim ( $p>0,05)$, fizyolojik $(p>0,05)$, estetik $(p>0,05)$, rahatlama $(p>0,05)$, sosyal $(p>0,05)$, psikolojik $(p>0,05)$ tatminlerinin ve genel olarak serbest zaman tatminlerinin ( $\mathrm{p}>0,05)$ anlamlı bir farklılık göstermediği belirlenmiştir. Başka bir ifadeyle 21 yaş ve altındaki sporcularla 21 yaşın üstündeki sporcuların serbest zaman tatminlerinin hem alt boyutlarda hem de genel olarak benzerlik gösterdiği tespit edilmiştir. Yaman (2016) ve Demiral (2018),tarafindan yapılan çalışmalarda yaş özerliği bakımından anlamlı bir farklılığa ulaşılmazken, Serdar (2016), tarafından yapılan çalışmada psikolojik ve rahatlama alt boyutlarında anlamlı farklılar görülmüştür. Yiğit (2018) tarafindan yapılan çalışmada sadece psikolojik alt boyutunda anlamlı bir farklılık bulunmuştur. Genel olarak baktığımızda diğer çalışmalar ile bizim çalışmamızın paralellik gösterdiğini ve serbest zaman tatmininin yaş değişkini açısından anlamlı bir fark yaratmadığını söyleyebiliriz.

Katıllımciların günlük serbest zaman sürelerine göre ESBAE alt boyutlarında "aerobik uygunluklarının ( $>0,05)$ ", "anaerobik uygunluklarının ( $\mathrm{p}>0,05)$ " anlamlı bir farklılık göstermediği tespit edilmiştir. Diğer bir ifadeyle günlük serbest zamanı 1-2 saat, 3-4 saat, 5-6 saat olan sporcuların aerobik ve anaerobik uygunluklarına yönelik algılarının benzerlik gösterdiği belirlenmiştir. Sporcularının "algıladıkları becerilerinin $(p<0,05)$ ", "vücut uygunluklarını $(p<0,05)$ ", "zihinsel becerilerinin $(p<0,05)$ ", "genel performanslarının $(\mathrm{p}<0,05)$ " ve "genel sporcu benlik algilarının $(\mathrm{p}<0,05)$ )" günlük serbest zamanlarına göre anlamlı bir değişiklik gösterdiği tespit edilmiştir. Günlük serbest zamanı 5-6 saat olan sporcuların sporcu benlik algilarının $(140,65 \pm 9,34)$; serbest zamanı 1 -2 saat $(124,83 \pm 20,08)$ ve $3-4$ saat $(128,90 \pm 18,28)$ olan sporculardan anlamlı bir şekilde daha yüksek düzeyde olduğu tespit edilmiştir. Bulgular çerçevesinde günlük serbest zaman süresinin benlik algisı üzerinde doğru orantılı bir şekilde arttığını söyleyebiliriz. SZTÖ alt boyutlarına baktığımızda üniversitede öğrenim gören bocce sporcularının eğitim ( $\mathrm{p}>0,05)$, fizyolojik ( $p>0,05)$, estetik ( $p>0,05)$, rahatlama $(p>0,05)$, sosyal $(p>0,05)$ ve psikolojik $(p>0,05)$ tatminleri günlük serbest zamanlarına göre anlamlı bir farkl1lık göstermemektedir. Benzer şekilde sporcuların günlük serbest zamanlarına göre serbest zaman tatminlerinin anlamlı bir değişiklik göstermediği belirlenmiştir ( $p>0,05)$. Başka bir anlatımla günlük serbest zamanı 1-2 saat, 3-4 saat, 5-6 saat olan sporcuların serbest zaman tatminlerinin genel olarak ve tüm alt boyutlarda benzerlik gösterdiği tespit edilmiştir. Bu sonuçla serbest zaman tatminin süresinin önemli olmayıp niteliğinin ve nasıl kullanıldığının önemli olduğunu söyleyebiliriz.

Katılımcıların millilik derecesi değişkenine göre ESBAE alt boyutlarında sporcularının millilik derecesine göre vücut uygunluklarının $(p>0,05)$, aerobik uygunluklarının $(p>0,05)$ ve anaerobik uygunluklarının $(\mathrm{p}>0,05)$ anlamlı bir değişiklik göstermediği görülmektedir. Diğer bir ifadeyle A milli, B milli ve C milli takımında oynayan sporcuların vücut, aerobik ve anaerobik uygunluklarına yönelik algılarının benzerlik gösterdiği tespit edilmiştir. Bocce sporcularının algıladıkları becerilerinin $(\mathrm{p}<0,05)$, zihinsel becerilerinin $(p<0,05)$, genel performanslarının $(p<0,05)$ ve genel olarak benlik algilarının $(p<0,05)$ anlamlı bir farklılık gösterdiği tespit edilmiştir. C millideki bocce sporcularının genel olarak benlik alg1larının $(123,88 \pm 19,84)$ B millideki sporculardan $(135,69 \pm 13,00)$ anlamlı bir şekilde daha düşük olduğu tespit edilmiştir. SZTÖ alt boyutları açısından incelediğimizde sporcularının millilik derecesine göre psikolojik tatminlerinin anlamlı olarak farklılık yaratmadığı belirlenmiştir ( $\mathrm{p}>0,05)$. Bocce sporcularının eğitim ( $p<0,05)$, fizyolojik $(p<0,05)$, estetik $(p<0,05)$, rahatlama $(p<0,05)$, sosyal $(p<0,05)$ tatminlerinin ve genel olarak serbest zaman tatminlerinin $(p<0,05)$ sporcuların millililik derecesine göre anlamlı bir değişiklik gösterdiği belirlenmiştir. C milli derecesindeki sporcuların serbest zaman tatminlerinin $(158,11 \pm 22,13)$ anlamlı bir biçimde daha düşük olduğu bulunmuştur. Bu sonuçlar bize millik derecesinin dolayısıyla yapılan sportif faaliyetlerdeki başarı ve tecrübenin serbest zaman tatmini üzerinde olumlu yönde etkilediğini göstermektedir. Millilik derecesi ve başarı arttıkça serbest zaman tatmininin arttığını söyleyebiliriz. 
ESBAE ve SZTÖ ile elde ettiğimiz bulgularla katılımcıların benlik algıları ile serbest zaman tatmin düzeyleri arasındaki ilişkiyi incelediğimizde araştırma kapsamında görüşleri alınan sporcuların benlik algıları ile eğitim ( $p .<0,01)$, rahatlama ( $<<0,01)$, fizyolojik $(p<0,01)$, psikolojik $(p<0,01)$, sosyal $(p<0,01)$ ve estetik $(\mathrm{p}<0,01)$ tatminleri arasında pozitif yönde ve orta düzeyde ilişkiler olduğu tespit edilmiştir. Üniversitede ögrenim gören bocce sporcularının benlik algıları ile serbest zaman tatminleri arasında pozitif olarak ve orta seviyede bir ilişki olduğu belirlenmiştir $(p<0,01)$.

Sonuç olarak üniversitede öğrenim gören elit düzey bocce sporcularının benlik algılarının yüksek olduğunu söyleyebiliriz. Rekreasyon faaliyetleri tatmin düzeylerinin de yüksek olduğu karşımıza çımaktadır. Bocce sporcularının benlik algıları ile serbest zaman tatminleri arasında pozitif yönde ve orta düzeyde bir ilişki olduğu belirlenmiştir. Bireyin benlik algısının yüksek olması onu kendine uygun olan, keyif alabileceği, mutlu olabileceği rekreasyon faaliyetlerine yönelmesinde etkili olduğu söylenebilir. Böylelikle kişi yaptı̆̆ rekreatif etkinliklerde tatmin olmaktadır. Çalışmadan elde edilen sonuçlar neticesinde öneri olarak;

1. Bocce sporu ve sporcuları üzerine kaynak çalışmalarının az olması sebebi ile bu konu üzerine çalışmalar yapılabilir.

2. Çalışma diğer branşlarda faaliyet gösteren elit sporculara uygulanabilir.

3. Bireylerin olumlu bir fiziksel benlik algısına sahip olmaları için, kas ve iskelet sistemini güçlendiren, kuvvet gerektiren fiziksel aktiviteleri gerçekleştirmeleri tavsiye edilebilir.

\section{Kaynakça}

Büyüköztürk, Ş, Çakmak E. K, Akgün, Ö. E., Karadeniz, Ş. ve Demirel, F. (2016). Bilimsel araştrma yöntemleri (20. Baskı). Ankara: Pegem Akademi Yayınları.

Çağlar, E., Aşçı, H. ve Kelecek, S. (2017). Elit sporcu benlik alg1sı envanteri türkçe uyarlaması: Geçerlik ve güvenirlik çalısması. Spormetre, 15(4), 165-172.

Çakır, O. V. (2017). Üniversite öğrencilerin serbest zaman doyum düzeyleri ile serbest zaman yönetimleri arasındaki ilişki. Gąiantep Üniversitesi Spor Bilimleri Dergisi, 2(3), 17-27.

Caldwell, L., Smith, E. ve Weissenger, E. (1992). The relationship of leisure activities and perceived health of college students. Society and Leisure, 15(2), 545-556.

Coşkun, Y. ve Altay, C.A. (2009). Lise öğrencilerinde yabanc1laşma ve benlik algisı ilişkisi. Marmara Üniversitesi, Atatïrk Eğitim Fakültesi Ë̆itim Bilimleri Dergisi, 29, 41-56.

Demiral, S. (2018). Açle alan rekereasyonuna katulan bireylerin serbest z̧aman tatmin dǚeylerinin incelenmesi: Şavssat-Karagöl örneği (Yüksek Lisans Tezi). Batman Üniversitesi, Batman.

Du Cap, M. C. (2002). The perceived impact of the acadia advantage program on the leisure lifestyle and leisure satisfation of the students at Acadia University (Unpublished Master Thesis). Acadia University, Ottowa.

Frankel, J. R. ve Wallen, N.E. (2009). How to design and evaluate research in education. (7th edition). Boston: McGraw-Hill.

Gökçe, H. (2015). Rekreasyonel etkinliklerin üniversiteye giris smavna hažrlanan bireylerin öz-yeterlik snav kaygısı ve serbest zaman doyum düzeyleri ǚrerine etkisi (Doktora Tezi). Sağllk Bilimleri Enstitüsü, Ankara Üniversitesi, Ankara.

Huang, C. Y. (2003). The relationships among leisure participation. leisure satisfaction, and life satisfaction of college students in Taiwan (PhD Thesis). University of the Incarnate Word, Faculty of the Graduate School.

Özkalp E. (1997). Davramıs Bilimlerine Giriş. Eskişehir: Anadolu Üniversitesi Yayınları.

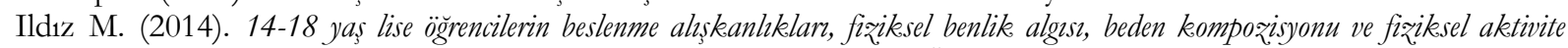
dïzeylerinin incelenmesi. Yüksek Lisans Tezi, Muğla Sıtkı Koçman Üniversitesi, Muğla.

Karasar, N. (2008). Bilimsel araștrma yöntemi. Ankara: Nobel Yayınc1lık

Karlı, Ü., Polat, E., Yılmaz, B. ve Koçak, S. (2008). Serbest zaman tatmin ölçeği geçerlilik ve güvenilirlik çalısması. Hacettepe Universitesi Spor Bilimleri Dergisi, 19(2), 80-91.

Kuru, E. (2003). Farklı statüdeki beden eğitimi bölümü öğrencilerinin kişilik özellikleri. Gazi Eğitim Fakïltesi Dergisi, 23(1), 175-191.

Kuzgun, Y. (1996). Akademik, benlike kavrami ölgeği. Ankara: MEB Yayınları.

Milli Eğitim Bakanlı̆̆1 (2013). Cocuk Gelişimi ve Eğitimi : “Sosyal Gelişim”. 4-23, Ankara.

Marsh H. W., Hey, J., Johnson, S. ve Perry, C. (1997). Elite athlete self-description questionnaire: Hierarchical confirmatory factor analysis of responses by two distinct groups of athletes. Int J Sport Psychol, 28, 237-258.

Murphy, H. (2003). Exploring leisure and psychological health and well being: Some problematic ,ssues in the case of Northern Ireland. Leisure Studies, 22(1), 37-50.

Özkalp, E. (1997). Davramış Bilimlerine Giriş. Eskişehir: Anadolu Üniversitesi Yayınları.

Pehlivan, Z. (2010). Beden eğitimi öğretmen adaylarının fiziksel benlik algiları ve öğretmenlik mesleğine yönelik tutumlarının analizi. Eğitim ve Bilim Dergisi, 35, 126-141.

Serdar, E. (2016). Üniversite ögrencilerinin katuldiklarn serbest zaman etkinliklerinden tatmin olma ve algzlanan özgürlïk dürzylerinin incelenmesi (Yüksek Lisans Tezi). Marmara Üniversitesi, İstanbul. 
Siegenthaler, K. L. ve O'Dell, I. (1998). Meeting the leisure needs of families. Journal of Parks and Recreation, 33(12), 3843.

Şener, A. (2009). Yaşlilık, yaşam doyumu ve boş zaman faaliyetleri. Çăğn Polisi Dergisi, 5(3), 60-69.

Tekin, G, Amman, M. T. ve Tekin, A. (2009). Serbest zamanlarda yapılan fiziksel egzersizin üniversite öğrencilerinin depresyon ve atılganlık düzeylerine etkisi. Uluslararası Insan Bilimleri Dergisi, 6(2), 148-159.

Tükenmez, H.(2014). Petank ve antrenman teknikleri. İzmir: Arvo Yayıncilik.

Türkmen, M. (2011). Cim topu, petank, raffa ve volo oyun sistemleriyle; bocce tanımlar, tarihşe ve oyun kurallar. Ankara: Neyir Yayınları.

Yaman, B. (2016). Gençlik merkezi faaliyetlerine katılan bireylerin serbest zaman tatmin düzeylerinin incelenmesi (Yüksek Lisans Tezi). Gazi Üniversitesi, Ankara.

Yaşartürk, F., Bilgin, Ü. ve Yaman, M. (2017). Determination of the recreative tendencies of high school and college students (Bartin province sample). The Online Journal of Recreation and Sport, 6(1), 17-31.

Yavuzer, H. (2001). Ana-baba ve çocuk. İstanbul: Remzi Kitabevi.

Yiğit, İ. (2018). Üniversite topluluklarnda rekreatif faaliyetlere katılan bireylerin serbest zaman tatmin düzeylerinin incelenmesi. (Yüksek Lisans Tezi). İnönü Üniversitesi, Malatya.

Zorba E. (2001). Kamu personelinin rekreatif eğilimleri (Muğla İli örneği) (Yüksek Lisans Tezi). Muğla Üniversitesi, Muğla.

Zorba, E. (2006). Herkes için yassam boyu spor. Ankara: Nobel Yayıncilık.

\section{EXTENDED ABSTRACT}

The aim of this study is to investigate the relationship between satisfaction level and self-perception levels of the elite level bocce athletes studying at the university. In addition, satisfaction and selfperception levels of the elite level bocce athletes who studied at university were examined according to some variables and their relationship was determined.

106 (57 female and 49 male) volunteer elite level bocce athletes attended the study. In order to determine demographic characteristics as a data collection tool, personal information form was used. In order to measure the self-perception levels of the participants, the, Elite Athlete Self Description Questionnaire (EASDQ), which was developed by Mars, Hey, Johnson and Perry (1997), was used by Caglar, Asci and Kelecek (2017) with the Elite Sports Self-Perception Inventory, it evaluates the selfperception of athletes in their physical and mental fitness abilities required for success in sports. There are 29 items in six sub-dimensions which are perceived in the scale: skill, body fitness, aerobic fitness, anaerobic fitness, mental skills and general performance. The items in the scale are graded in 6-point Likert ( $1=$ Fully False and $6=$ Fully True) types. In order to determine the satisfaction levels of university students in terms of their free time evaluation, Leisure Satisfaction (LSS) Scale mek which was adapted to Turkish by Karli, Polat, Yilmaz and Kocak (2008) developed by Beard and Ragheb (1980) was used. There are 39 items in total in 6 dimensions: psychological, educational, social, relaxation, physiological and aesthetic. The items in the scale are rated in 5-point Likert type (almost non-valid for me - almost always valid for me). In the analysis of data, using SPSS 23.0 package program. Descriptive statistics, t-test, Kruskal Wallis, Pearson Correlation coefficient were analyzed.

According to demographic characteristics, $53.8 \%(\mathrm{n}=57)$ of the bocce athletes were female, $46.2 \%$ $(n=49)$ were male and $47.2 \%(n=50)$ were male. and $52.8 \%(n=56)$ were found to be 22 years of age. It was observed that $43.4 \%(n=46)$ of Bocce athletes stated that they had 1-2 hours free time per day. $37.7 \%$ $(n=40)$ of the athletes have a free time of 3-4 hours, while $18.9 \%(n=20)$ of them are 5-6 hours. In addition, $14.2 \%$ of the athletes $(n=15)$ A National, 33.0\% $(n=35)$ B National, $52.8 \%(n=56)$ C has a national degree.

The perceived skill of athletes $\left(\mathrm{t}_{(104)}=1,998 ; \mathrm{p}<0,05\right)$, body fit $\left(\mathrm{t}_{(104)}=2,724 ; \mathrm{p}<0,05\right)$, aerobic fitness $\left(\mathrm{t}_{(104)}=2,617 ; \mathrm{p}<0,05\right)$, general performance $\left(\mathrm{t}_{(104)}=2,208 ; \mathrm{p}<0,05\right)$, and in general athletes self-perceptions $\left(\mathrm{t}_{(104)}=2,581 ; \mathrm{p}<0,05\right)$ showed significant differences according to their gender. Training according to the gender of the athletes of Bocce $\left(\mathrm{t}_{(104)}=1,093 ; \mathrm{p}>0,05\right)$, physiological $\left(\mathrm{t}_{(104)}=0.032 ; \mathrm{p}>0.05\right)$, aesthetics $\left(\mathrm{t}_{(104)}=0.102 ; \mathrm{p}>0.05\right)$, relaxation $\left(\mathrm{t}_{(104)}=0.921 ; \mathrm{p}>0.05\right)$, social $\left(\mathrm{t}_{(104)}=0.643 ; \mathrm{p}>0.05\right)$. Bocce athletes studied at universities according to their age perceived skill $\left(\mathrm{t}_{(104)}=2.135 ; \mathrm{p}<0.05\right)$, body suitability $\left(\mathrm{t}_{(104)}=2,869\right.$; $\mathrm{p}<0,05)$, anaerobic fitness $\left(\mathrm{t}_{(104)}=2,473 ; \mathrm{p}<0,05\right)$, general performance $\left(\mathrm{t}_{(104)}=2,704 ; \mathrm{p}<0,05\right)$, and generally athletes self-perceptions $\left(\mathrm{t}_{(104)}=2,800 ; \mathrm{p}<0,05\right)$ showed significant differences. Bocce athletes training $\left(\mathrm{t}_{(104)}=0,865 ; \mathrm{p}>0,05\right)$, physiological $\left(\mathrm{t}_{(104)}=1,856 ; \mathrm{p}>0,05\right)$, aesthetics $\left(\mathrm{t}_{(104)}=0,329 ; \mathrm{p}>0,05\right)$, relaxation $\left(\mathrm{t}_{(104)}=1,290 ; \mathrm{p}>0,05\right)$, social $\left(\mathrm{t}_{(104)}=0,722 ; \mathrm{p}>0,05\right)$, psychological $\left(\mathrm{t}_{(104)}=1,169 ; \mathrm{p}>0,05\right) \quad\left(\mathrm{t}_{(104)}=1.359\right.$; $\mathrm{p}>0.05)$ did not show a significant difference. 
Bocce athletes' perceived skills $\left(\mathrm{X}^{2}{ }_{(2}=9,142 ; \mathrm{p}<0,05\right)$, body fitness $\left(\mathrm{X}^{2}{ }_{(2)}=19,280 ; \mathrm{p}<0,05\right)$, mental skills $\left(\mathrm{X}^{2}{ }_{(2)}=13,803 ; \mathrm{p}<0,05\right)$, general performances $\left(\mathrm{X}^{2}(2)=16,144 ; \mathrm{p}<0,05\right)$ and general athletes selfperceptions $\left(\mathrm{X}^{2}(2)=10,911 ; \mathrm{p}<0,05\right)$ has been found to show a significant change compared to the daily free time. bocce athletes studying at university $\left(\mathrm{X}^{2}(2)=0,156 ; \mathrm{p}>0,05\right)$, physiological $\left(\mathrm{X}^{2}(2)=3,695 ; \mathrm{p}>0,05\right)$, aesthetics $\left(\mathrm{X}_{(2)}^{2}=0,002 ; \mathrm{p}>0,05\right)$, relaxation $\left(\mathrm{X}^{2}(2)=0.881 ; \mathrm{p}>0.05\right)$, social $\left(\mathrm{X}_{(2)}{ }_{(2)}=0.737 ; \mathrm{p}>0.05\right)$ and psychological $\left(\mathrm{X}^{2}(2)=1.753 ; \mathrm{p}>0.05\right)$ Satisfied satisfaction with daily free time does not show a significant difference. Bocce athletes perceived skills $\left(X^{2}{ }_{(2)}=11,461 ; p<0,05\right)$, mental skills $\left(X^{2}{ }_{(2)}=12,600 ; p<0,05\right)$, the overall performance $\left(X^{2}(2)=12,600 ; p<0,05\right)$ and overall self-perceptions $\left(X^{2}(2)=7,650 ; p<0,05\right)$. Education of bocce athletes at universities $\left(\mathrm{X}^{2}(2)=12,437 ; \mathrm{p}<0,05\right)$, physiological $\left(\mathrm{X}^{2}(2)=6,718 ; \mathrm{p}<0,05\right)$, aesthetics $\left(\mathrm{X}_{(2)}^{2}=20,380 ; \mathrm{p}<0,05\right)$, relaxation $\left(\mathrm{X}^{2}(2)=20,354 ; \mathrm{p}<0,05\right)$, social $\left(\mathrm{X}_{(2)}^{2}=13,172 ; \mathrm{p}<0,05\right)$ satisfaction in general and free time satisfaction $\left(\mathrm{X}_{(2)}^{2}=12,550 ; \mathrm{p}<0.05\right)$.

It was determined that athletes showed a significant change according to their nationality. When we examined the relationship between self-perceptions and free time satisfaction levels of the participants with the findings obtained with EASDQ and LSS, the self-perceptions of the athletes who received their opinions within the scope of the study were studied $(\mathrm{p}<0.01)$, relaxation $(\mathrm{p}<0.01)$, physiological $(\mathrm{p}<0,01)$, psychological $(\mathrm{p}<0,01)$, social $(\mathrm{p}<0,01)$ and aesthetic $(\mathrm{p}<0,01)$ satisfaction between the positive and moderate level of relationships were determined. It was determined that bocce athletes studying at the university had a positive and moderate relationship between self-perceptions and free time satisfaction $(\mathrm{p}<0.01)$. As a result, we can say that elite level bocce athletes studying at university have high selfperceptions. It is also observed that the satisfaction levels of recreation activities are high. Bocce athletes have a positive and moderate relationship between self-perceptions and free time satisfaction. The high self-perception of the individual can be said to be effective in his orientation towards recreation activities which he can enjoy and be happy. Thus, the person is satisfied with his recreational activities. 